\title{
Ichthyofauna diet changes in response to urbanization: the case of upper Paranapanema River basin (Brazil)
}

\author{
Alexandre Peressin ${ }^{1}$ (D) Cristina da Silva Gonçalves ${ }^{2} \cdot$ Mauricio Cetra $^{3}$
}

Published online: 4 April 2018

(C) Springer Science+Business Media, LLC, part of Springer Nature 2018

\begin{abstract}
Alterations in stream environments can alter fish food availability, but there is little research data related to the impacts of urbanization on fish diets in tropical streams. Thus, we sought to compare the diet of ten fish species in urbanized and nonurbanized streams reaches. Fish stomach contents were obtained for four urban and five non-urban stream reaches from two medium-sized cities. We verified the similarity of diet composition from urbanized/non-urbanized streams. In-stream features mainly related to the substrate highlighted a perturbation gradient: gravel, pebbles and cobbles were associated to the wider urban reaches while silt were representative in the narrow pools from non-urban streams. Fishes changed their diet in response to urban and non-urban treatments. Omnivorous fishes consumed more detritus and Chironomidae and less terrestrial adult insects in urban reaches, while invertivorous fish consumed more terrestrial adult insects and Trichoptera larvae in the non-urbanized stream reaches. Although the management of the physical structure of streams in Brazil has been basically focused on riparian reforestation, our results suggest that a restoration plan for urban streams cannot be limited to reforestation of its surroundings, but also need to consider the physical structure of the channel, especially the substrate, which contributes to promote in-stream variability.
\end{abstract}

Keywords Invertivorous $\cdot$ Omnivorous $\cdot$ Detritus $\cdot$ Chironomidae

Alexandre Peressin

alexandre.peressin@gmail.com

Cristina da Silva Gonçalves

cristina.silva.goncalves@gmail.com

Mauricio Cetra

mcetra@ufscar.br

1 Programa Peixe Vivo - Companhia Energetica Minas Gerais (Cemig), Av. Barbacena, 1200, Santa Agostinho, Belo Horizonte 30190-131, Brazil

2 Departamento de Zoologia, Universidade Estadual Paulista "Júlio de Mesquita Filho" (UNESP), Av. 24A, 1515, 13506-900, Rio Claro, São Paulo, Brazil

3 Departamento de Ciências Ambientais (DCA), Universidade Federal de São Carlos (UFSCar) - Sorocaba, Rodovia João Leme dos Santos (SP 264), km 110, 18.052-780, Sorocaba, São Paulo, Brazil

\section{Introduction}

South American freshwaters are characterized by high biodiversity, which is threatened by multiple social and economic pressures (Dudgeon et al. 2006; Barletta et al. 2010). Among these, urbanization is one of the major conservation challenges for stream fauna (Allan 1995; Paul and Meyer 2001). The substitution of natural land cover by anthropogenic construction often causes channel modification, which in turn can alter the resident aquatic fauna (Lammert and Allan 1999; Nerbonne and Vondracek 2001; Esselman and Allan 2010; Cunico et al. 2012; Cruz et al. 2013; Casatti et al. 2015). Changes in assemblage composition, trophic structure and in the reproductive guilds are reported as consequences of urbanization on ichthyofauna (Helms et al. 2005; Cunico et al. 2006; Roy et al. 2006; Peressin and Cetra 2014). However, despite widespread alteration of stream fish by urbanization, most studies are focused on water quality and broad environmental issues such as human health (Francis 2012). 
Substrate composition, meso-habitat availability and riparian vegetation integrity can alter fish assemblages directly, by offering shelter, feeding and spawning habitat and nursery sites (Casatti et al. 2006) or indirectly, by influencing food availability (Luiz et al. 1998; Bojsen and Barriga 2002; Bojsen 2005; Wantzen et al. 2008; Lorion and Kennedy 2009; Ferreira et al. 2012). These environmental properties influence algae (Daruich et al. 2013; Hlúbiková et al. 2014), macrophytes (Suren 2000; Karpova and Klepets 2014) and aquatic invertebrates (Jacobsen et al. 2008; Vermonden et al. 2009; Collier 2014) assemblages, thus it is reasonable to suppose that urbanization also can lead to changes in food availability to the fish.

Fish trophic structure is usually an important indicator of environmental health (Casatti et al. 2009a), thus, dietary studies along environmental gradients may improve the understanding of fish assemblage response to urban disturbance. The trophic plasticity of Neotropical fish allows their adaptation to changes in food supply and has been documented in the literature (e.g. AraujoLima et al. 1995; Lowe-McConnell 1999). According to these authors, Neotropical fishes have great alimentary flexibility in time and space, which allows fairly rapid adaptation to change in food supply. Thus, fish diet reflects the availability of food (Rezende et al. 2013; Tófoli et al. 2013), and resource availability can be studied analyzing fish stomach contents (Zeni and Casatti 2014). The trophic status of species should also be considered in diet studies to detect shifts in food avalilability, since previous work have shown that this introduces variability (Abujanra et al. 2009; Luz-Agostinho et al. 2009; Sato and Godinho 1999).

The well-defined physical structure and small size of streams make them good models for evaluating the effect of physical impacts on aquatic communities (Herder and Freyhoff 2006). According to Ramírez et al. (2008), there is still basic knowledge to be acquired before understanding how the ichthyofauna of tropical streams responds to anthropogenic impacts. Although there are many studies on the impacts of urbanization on streams, they are heavily concentrated in North America, Europe and Asia (Francis 2012), comprising mainly temperate streams. However, there is evidence that the food resource availability and fish trophic structure of tropical streams are different compared to temperate streams (Boulton et al. 2008). The relative paucity of studies on the impacts of urbanization on Neotropical streams indicates a critical knowledge gap. Therefore, this study sought to evaluate changes in fish diets in urban and non-urban streams.

Specifically, we seek to answer the following questions: 1Does urbanization alter fish diet? 2- Do individual fish species show flexibility in their diet in response to urbanization? And 3- Are changes in diet related to environmental variables?

\section{Materials and methods}

\section{Study area and field sampling}

All streams in this study are tributaries of the Upper Paranapanema River basin, southwestern region of the state of São Paulo (Fig. 1). The study area encompasses the cities of Pilar do Sul and São Miguel Arcanjo. We sampled nine stream reaches, between August and December 2010 and 2011. The choice of streams was primarily based on the proximity of urban or non-urban areas. Three streams were inside in the urban area of Pilar do Sul (U1, U2, U3), and one of São Miguel Arcanjo (U4) (Fig. 1). For the five non-urban (NU) reaches, we selected reaches without upstream urban development. We selected wadeable streams to allow the use of electrofishing. The urban portion of Pilar do Sul has $13.00 \mathrm{~km}^{2}$ where 20,731 inhabitants live (Population density $=1594.69$ / $\mathrm{km}^{2}$ ) and the urban area of São Miguel Arcanjo has $18.32 \mathrm{~km}^{2}$ supporting a population of 21,499 inhabitants (Population density $=1173.53 / \mathrm{km}^{2}$ ) (Fundação SEADE 2013). The cities of Pilar do Sul and São Miguel Arcanjo collected 97\% and $92 \%$ of its sewage during 2006 and both cities treat $100 \%$ of the sewage collected. In non-urban area, there was a predominance of natural vegetation and agricultural activities, mainly pastures formed by Brachiaria sp. and reforestation by Eucalyptus spp. Fragments of semi-deciduous tropical forest, cerrado and lowland forests compose the natural vegetation, covering $15 \%$ of the basin area.

\section{Fish sampling and environmental data}

Fish were collected during the dry season in AugustNovember 2010/11 during daytime hours by electrofishing using a portable gasoline generator (Yamaha EF2600 model, $2.3 \mathrm{kVA}, 60 \mathrm{~Hz}$ ) linked to a current rectifier. In each stretch, a single downstream-upstream sweep was performed, without block nets at the upper and lower limits. We selected streams stretches of $70 \mathrm{~m}$ in length presenting at least one pool-andriffle sequence, which provides a heterogeneous physical environment that is utilized by many different types of organisms (Fryirs and Brierley 2013). In the dry season, the relationship between fish assemblages and water conditions in the streams was expected to be more robust, since flows are lower and fish can be captured more efficiently (Pinto et al. 2006; Pease et al. 2012). Furthermore, this ensured only direct dispersal interactions between sites, with no confounding in the data through multiple dispersal events, which occurs in the rainy season (Cottenie 2005). This sampling protocol has been efficiently used to collect fishes inhabiting small (width $\approx 5 \mathrm{~m}$ ) tropical headwater streams (Gonçalves and Braga 2012; Ferreira et al. 2014).

We measured 18 variables to characterize the stream reach environment. Bank stability was visually estimated as the 
Fig. 1 Non-urban (NU) and urban (U) sites located in Pilar do Sul (PS) and São Miguel Arcanjo (SMA) municipalities (Brazil)

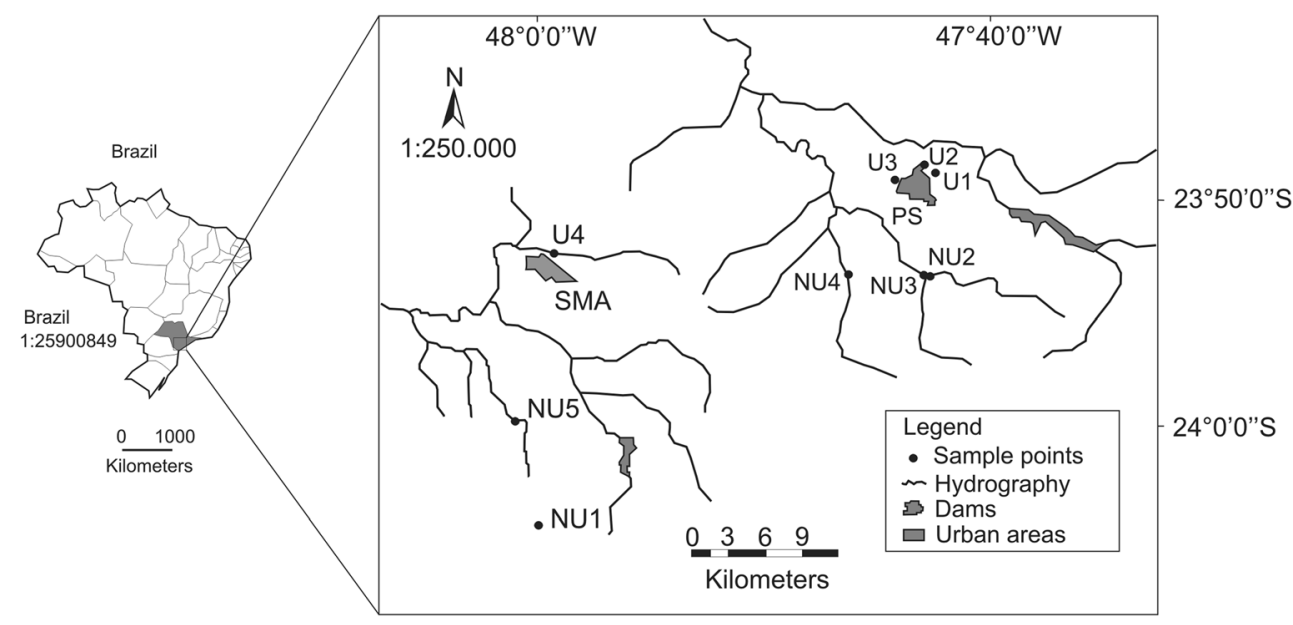

percentage of rocks, tree roots, tree trunks, steep slopes, and exposed soil in both banks at three transects positioned perpendicular to the 70-m reach. Transects were separated by 20 $25 \mathrm{~m}$ and selected to represent upper, middle, and low sections of the reach. Shading was visually estimated as the percentage of shaded and lighted areas within the 70-m stream reach. To characterize the riparian vegetative zone, we visually estimated the percentage $(\%)$ of the site-scale riparian vegetation within a $30 \mathrm{~m}$ along both sides of the sampling reach.

Channel morphology and flow velocity were recorded during onsite surveys and were taken at 1-m intervals in the three transects. Channel morphology was defined in terms of the mean of the width and depth measurements. Flow velocity was measured with a mechanical General Oceanics model 2030 flowmeter at the middle of the water column and described in terms of mean values recorded every meter along the three transects. The percentage of the meso-habitats runs, riffles and pools (sensu Harding et al. 2009) were visually estimated. Substrate composition included the percentage of silt, sand, gravel, pebbles, cobbles, and boulders estimated at $1-\mathrm{m}$ intervals along transects. To measure substrate variables, we visually estimated the composition of consecutive $1-\mathrm{m}^{2}$ plots along each transect and scored substrate composition in an ordinal scale as $1,2,3$, or 4, meaning $<25,26-50,51-$ $75,>75$ percentage composition, respectively. Physical and chemical variables including temperature, $\mathrm{pH}$ and conductivity were measured once at a single point near a bank of the middle transect using portable analytical equipment (Marte MB-10P and Marte MB-11P).

\section{Stomach content analysis}

In the laboratory, fish were dissected and only full stomachs were removed, weighed $(\mathrm{g})$ and stored in $70 \%$ ethanol. Stomach contents were identified at the lowest possible taxonomic level (generally family level). For diet analysis, food items were assigned values according to the method of Degree of Food Preference (DFP) (Braga 1999). For the calculation of DFP we first assigned values of importance of each of the items in the fish stomachs. Value of 4 is assigned in the case that only one item is present in the stomach. In cases where there was more than one item in the stomach, values 3,2 or 1 were assigned, according to the relative proportion of the item in the stomach contents analyzed. The most abundant item was assigned value 3 ; the least abundant was assigned value 1 and the intermediate item was assigned value 2 . In cases where $>3$ items were present, two or more was assigned the same value, according to the method described above. A DFP value was calculated for each stomach item according to the following: $\mathrm{DFP}=\mathrm{S}(\mathrm{i}) / \mathrm{N}$, where $\mathrm{S}(\mathrm{i})$ is the sum of the values assigned to each item $\mathrm{i}$ and $\mathrm{N}$ is the total number of analysed stomachs.

\section{Data analysis}

A Principal component analysis (PCA) was used to reduce the dimensionality of the environmental data. The variables were standardized by maximum, and the number of principal components was determined by the broken-stick method.

Fish species were assigned to trophic categories based on the literature. In stomach content analysis, we considered five items: vegetal material (fruits, seeds and leaves), detritus, terrestrial adult insect (adults of Coleoptera, Diptera, Ephemeroptera and Hymenoptera), Trichoptera larvae and Chironomidae larvae. Trichoptera larvae was chose becaused this taxa is often pointed as good health environmental indicator (Collier 1995; Cavaca et al. 2014), while Chironomidae larvae - although being also an important resource for fish in natural environments (Rezende et al. 2013), is a family with species recognized by their tolerance to environmental degradation (Lammert and Allan 1999; Nerbonne and Vondracek 2001).

Considering only species sampled in urban and non-urban stream reaches, the similarity in DFP profiles was determined 
using the Bray-Curtis distance metric. Non-metric multidimensional scaling (NMDs) was performed separately on urban vs non-urban, and the point clouds were aligned using Procrustes and a procrustes superimposition plot was performed (Peres-Neto and Jackson 2001). Procrustes analysis attempts to stretch and rotate the points in one matrix (non-urban), such as points obtained by NMDs, to be as close as possible to points in the other matrix (urban), thus preserving the relative distances between points within each matrix. To verify if the concordance between the two matrices is not bigger than expected at random we used the Protest. The Protest uses a correlation-like statistic derived from the symmetric Procrustes sum of squares and tests the non-randomness between two configurations (functions procrustes and protest, vegan R-package, R Core Team 2013; Oksanen et al. 2017).

In order to check for differences in diet composition between urban and non-urban reaches and between the omnivorous and invertivorous trophic categories, a nonparametric multivariate analysis of variance of two factors (Two-way PERMANOVA) was applied, with 99,999 replications and Bray-Curtis similarity index $(\alpha<0.05)$. A percentage of similarity analysis (SIMPER) was used to check the total dissimilarity of diet composition and the average abundance of each item between urban and non-urban sections (Hammer et al. 2011).

\section{Results}

Stream reaches were environmentally heterogeneous (Table 1). The first two principal components from a PCA of environmental variables explained $65 \%$ of the total variation in the data set. The PCA1 represented a perturbation gradient and urban and non-urban stream reaches formed two visually distinct groups (Fig. 2). The PCA1 axis was negatively represented by width, gravel, pebbles and cobbles and was positively associated with percent pools and silt (Table 2).

Considering only species sampled in both urban and nonurban stream reaches, we captured 782 specimens belonging to three orders, five families and 10 species. One hundred and thirty-eight specimens had full stomachs that were analyzed (Table 3).

The DFP profiles of the species sampled in urban and nonurban stream reaches do not have similar patterns $(r=0.4825$, $p=0.192)$. The omnivorous Astyanax bockmanni and Phalloceros reisi have great residual values. On the other hand, the invertivorous Cetopsorhamdia iheringi, Piabina argentea and Pimelodella avanhandavae have small residual values (Table 4 and Fig. 3).

Considering both trophic categories, all items were consumed in urban and non-urban reaches, but in different amounts. Vegetal material was consumed in higher amounts
Table 1 Median, minimum and maximum values of the environmental variables

\begin{tabular}{lllll}
\hline & Variable & Median & Min & Max \\
\hline Channel morphology & Width (m) & 4.7 & 2.1 & 10.5 \\
& Depth (cm) & 36.0 & 11.2 & 50.2 \\
Flow velocity & Velocity (ms ${ }^{-1}$ ) & 0.40 & 0.15 & 0.86 \\
Mesohabitat & Riffles (\%) & 86 & 45 & 100 \\
& Run (\%) & 0 & 0 & 40 \\
Substrate composition & Pool (\%) & 11 & 0 & 50 \\
& Silt (\%) & 4 & 0 & 20 \\
& Sand (\%) & 8 & 0 & 15 \\
& Gravel (\%) & 9 & 0 & 36 \\
& Pebbles (\%) & 16 & 0 & 28 \\
Bank stability & Cobbles (\%) & 11 & 0 & 46 \\
Shading & Boulders (\%) & 2 & 0 & 58 \\
Riparian vegetation & Stability (\%) & 50 & 10 & 100 \\
Water & Shading $(\%)$ & 71 & 35 & 100 \\
& Riparian $(\%)$ & 5 & 0 & 100 \\
& Conductivity $(\mu \mathrm{S} / \mathrm{cm})$ & 30.3 & 24.1 & 128.3 \\
& pH & 7.2 & 6.0 & 7.4 \\
& Temperature $\left({ }^{\circ} \mathrm{C}\right)$ & 18.3 & 16.3 & 21.5 \\
\hline
\end{tabular}

in non-urban reaches and mainly by omnivorous. Only omnivorous fish consumed detritus, presenting a higher DFP for this item in urban reaches. Omnivores consumed Trichoptera larvae only in non-urban reaches. As omnivorous, invertivorous fish consumed a higher DFP of terrestrial adult insects in non-urban reaches. Omnivorous and invertivorous fish consumed more Chironomidae larvae in urban reaches (Table 5).

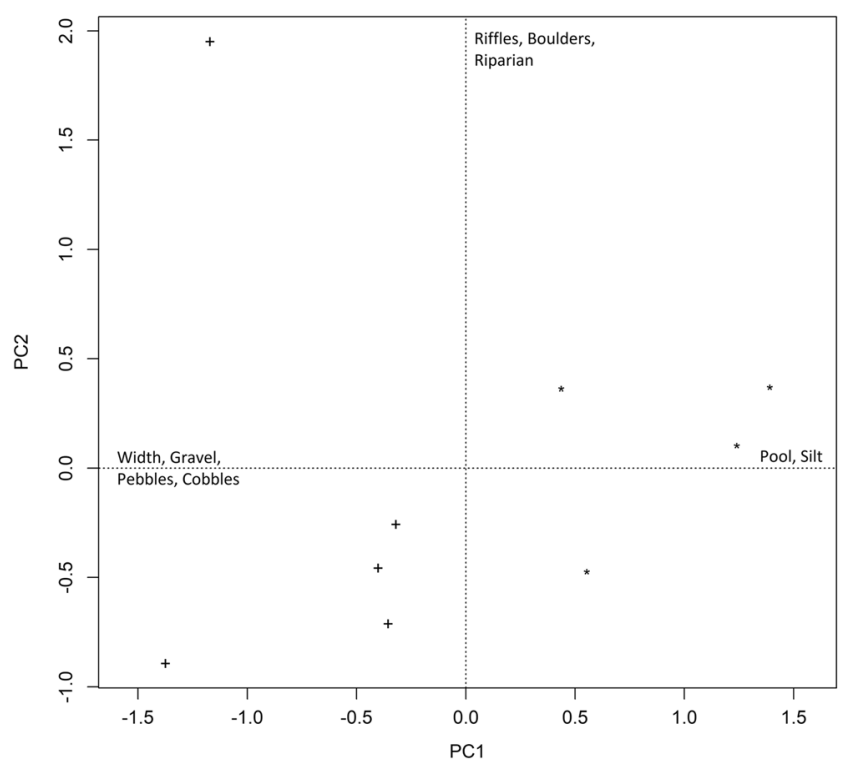

Fig. 2 Ordination plot of the PCA analysis with environmental variables. + non-urban and $*$ urban stream reaches 
Table 2 PCA output and variables scores (correlation values more than 0.7 in italic)

\begin{tabular}{lll}
\hline & PCA1 & PCA2 \\
\hline Variance & 7.27 & 4.34 \\
Broken-stick value & 6.11 & 3.86 \\
Cumulative variance explained & 0.40 & 0.65 \\
Width & -0.73 & 0.26 \\
Depth & -0.08 & -0.02 \\
Velocity & -0.35 & -0.52 \\
Riffles & -0.24 & 0.74 \\
Run & -0.51 & -0.56 \\
Pool & 0.73 & 0.12 \\
Silt & 0.67 & 0.00 \\
Sand & -0.20 & -0.39 \\
Gravel & -0.76 & -0.02 \\
Pebbles & -0.75 & 0.07 \\
Cobbles & -0.64 & -0.39 \\
Boulders & -0.40 & 0.66 \\
Stability & -0.36 & 0.45 \\
Shading & -0.56 & 0.32 \\
Riparian & -0.35 & 0.60 \\
Conductivity & -0.54 & -0.23 \\
pH & 0.52 & 0.35 \\
Temperature & -0.10 & -0.28 \\
\hline
\end{tabular}

Table 4 Pointwise residuals for each species from urban and non-urban stream reaches

\begin{tabular}{ll}
\hline Species & Residual values \\
\hline Astyanax bockmanni & 1.57 \\
Astyanax fasciatus & 0.57 \\
Piabina argentea & 0.45 \\
Characidium gomesi & 0.54 \\
Characidium zebra & 0.70 \\
Cetopsorhamdia iheringi & 0.19 \\
Imparfinis mirini & 0.78 \\
Pimelodella avanhandavae & 0.45 \\
Rineloricaria pentamaculata & 1.00 \\
Phalloceros reisi & 1.43 \\
\hline
\end{tabular}

In two-way PERMANOVA, omnivores vs. invertivores and urban vs. non-urban sections were statistically different in the diet of the fish. There was significant interaction between sources of variation trophic category and urbanization (Table 6).

The total average dissimilarity of diet composition between urban and non-urban sections was of $82.75 \%$. Detritus and Chironomidae larvae predominated in urban reaches while terrestrial adult insect, vegetal material and Trichoptera larvae prevailed in non-urban reaches (Table 7).
Table 3 Species and code, number of individuals (individuals) and number of stomachs (stomachs) analyzed in urban (U) and non-urban (NU) reaches. Total ind $=$ total number of individuals; Total sto $=$ total analyzed stomachs. $1=$ Casatti et al. (2009b); 2 = Casatti et al. (2012); 3 = Silva et al. (2012); $4=$ Smith et al. (2013)

\begin{tabular}{|c|c|c|c|c|c|c|c|}
\hline \multirow[t]{2}{*}{ Species (code) } & \multicolumn{2}{|c|}{ Individuals } & \multicolumn{2}{|c|}{ Stomachs } & \multirow[t]{2}{*}{ Total ind } & \multirow[t]{2}{*}{ Total sto } & \multirow[t]{2}{*}{ Trophic category } \\
\hline & $\mathrm{U}$ & NU & $\mathrm{U}$ & NU & & & \\
\hline \multicolumn{8}{|l|}{ Characiformes } \\
\hline \multicolumn{8}{|l|}{ Characidae } \\
\hline Astyanax bockmanni (Aboc) & 74 & 15 & 12 & 8 & 89 & 20 & Omnivorous $^{2}$ \\
\hline Astyanax fasciatus (Afas) & 48 & 37 & 11 & 13 & 85 & 24 & Omnivorous $^{2}$ \\
\hline Piabina argentea (Parg) & 5 & 21 & 4 & 11 & 26 & 15 & Invertivorous $^{1}$ \\
\hline \multicolumn{8}{|l|}{ Crenuchidae } \\
\hline Characidium gomesi (Cgom) & 9 & 19 & 5 & 3 & 28 & 8 & Invertivorous $^{2}$ \\
\hline Characidium zebra (Czeb) & 2 & 21 & 2 & 6 & 23 & 8 & Invertivorouss $^{2}$ \\
\hline \multicolumn{8}{|l|}{ Siluriformes } \\
\hline \multicolumn{8}{|l|}{ Heptapteridae } \\
\hline Cetopsorhamdia iheringi (Cihe) & 4 & 11 & 1 & 3 & 15 & 4 & Invertivorous $^{2}$ \\
\hline Imparfinis mirini (Imir) & 130 & 29 & 14 & 2 & 159 & 16 & Invertivorous $^{2}$ \\
\hline Pimelodella avanhandavae (Pava) & 91 & 140 & 8 & 9 & 231 & 17 & Invertivorous $^{2}$ \\
\hline \multicolumn{8}{|l|}{ Loricariidae } \\
\hline Rineloricaria pentamaculata (Rpen) & 3 & 22 & 3 & 4 & 25 & 7 & Omnivorous $^{3}$ \\
\hline \multicolumn{8}{|l|}{ Cypronodontiformes } \\
\hline \multicolumn{8}{|l|}{ Poeciliidae } \\
\hline Phalloceros reisi (Prei) & 77 & 24 & 11 & 8 & 101 & 19 & Omnivorous $^{4}$ \\
\hline Total & 443 & 339 & 71 & 67 & 782 & 138 & \\
\hline
\end{tabular}




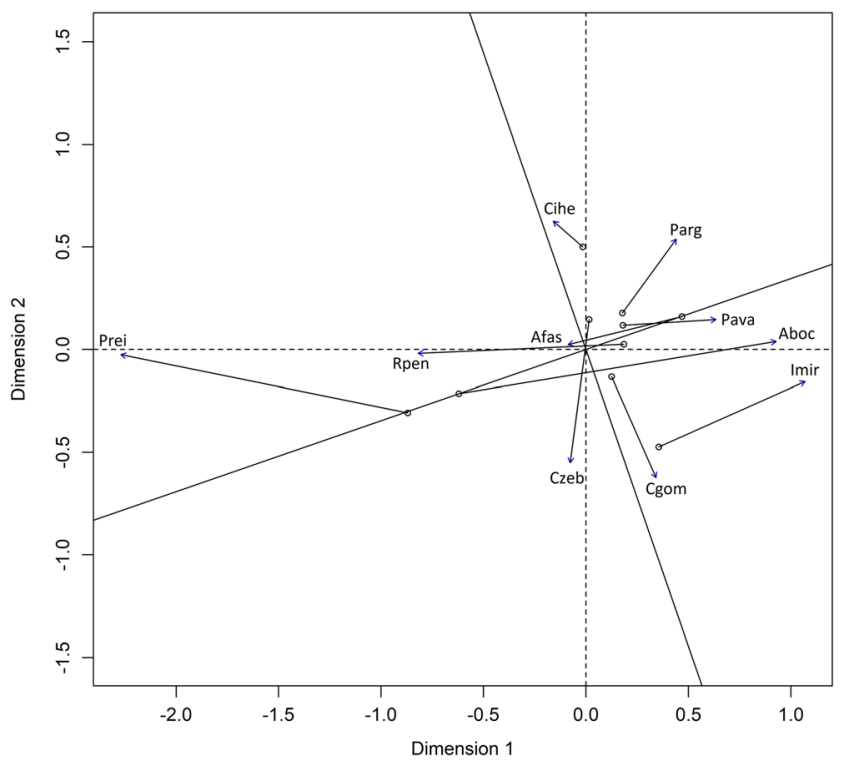

Fig. 3 Procrustes analysis of 10 species DFP sampled in urban and non-urban stream

\section{Discussion}

Fish diet in the upper Paranapanema River basin changed in response to urbanization. Urbanization lead invertivores fish to consume less terrestrial adult insects and Trichoptera larvae in urban sections. Omnivores, in turn, consumed more detritus and Chironomidae larvae in urban sections. The higher consumption of terrestrial insects and plant material by invertivores and omnivores in non-urban streams reflects good habitat quality, as well as the greater consumption of detritus in urban streams is related to a more disturbed habitat. Aquatic environments in non-urban areas, often have fish with specialized habits (e.g. terrestrial insectivores, benthonic, intolerant to oxygen-poor water, rheophilic species), unlike the fish of typically urban degraded streams (detritivores and omnivores, surface and tolerant species) (Casatti et al. 2012).

Table 5 Degree of food preference (DFP) for each item and trophic category in urban $(\mathrm{U})$ and non-urban $(\mathrm{NU})$ stream reaches. $\mathrm{N}=$ number of stomachs in which the item was present

\begin{tabular}{|c|c|c|c|c|c|c|c|c|}
\hline \multirow[t]{3}{*}{ Item } & \multicolumn{4}{|c|}{ Omnivore } & \multicolumn{4}{|c|}{ Invertivore } \\
\hline & \multicolumn{2}{|l|}{ DFP } & \multicolumn{2}{|l|}{$\mathrm{N}$} & \multicolumn{2}{|l|}{ DFP } & \multicolumn{2}{|l|}{$\mathrm{N}$} \\
\hline & $\mathrm{U}$ & NU & $\mathrm{U}$ & NU & $\mathrm{U}$ & NU & $\mathrm{U}$ & NU \\
\hline Vegetal material & 0.49 & 1.33 & 10 & 18 & 0.12 & 0.29 & 4 & 4 \\
\hline Detritus & 2.24 & 1.24 & 23 & 11 & 0 & 0 & 0 & 0 \\
\hline Terrestrial adult insects & 0.22 & 0.55 & 4 & 7 & 0.24 & 1.44 & 3 & 14 \\
\hline Trichoptera larvae & 0 & 0.03 & 0 & 1 & 0.15 & 0.41 & 3 & 9 \\
\hline Chironomidae larvae & 0.59 & 0.12 & 13 & 1 & 2.35 & 0.91 & 28 & 16 \\
\hline
\end{tabular}

Table 6 Two-way non-parametric multivariate analysis of variance (Two-way PERMANOVA) for urbanization (urban $\mathrm{x}$ non-urban reaches) and for trophic categories (Omnivores $\mathrm{x}$ invertivores). $\mathrm{SS}=$ sum of squares; $\mathrm{DF}=$ Degrees of freedom; $\mathrm{MS}=$ mean square; Statistical test $=\mathrm{F} ; \mathrm{p}=$ probability value. 99.999 permutations and $\alpha=0.05$

\begin{tabular}{llllll}
\hline Source & SS & DF & MS & F & P \\
\hline Urbanization & 3.03 & 1 & 3.03 & 10.90 & $0.00001^{*}$ \\
Trophic category & 8.88 & 1 & 8.88 & 31.87 & $0.00001^{*}$ \\
Interaction & 0.62 & 1 & 0.62 & 2.24 & $0.00244^{*}$ \\
Residual & 37.32 & 134 & 0.28 & - & - \\
Total & 49.86 & 137 & - & - & - \\
\hline
\end{tabular}

*indicates significant $p$ values; Bray-Curtis similarity index

Thus, detritivores, algivores or aquatic insectivores fish are common feeding habits in homogeneous streams while a greater diversity of trophic guilds is expected in heterogeneous streams (Zeni and Casatti 2014), reflecting an environment with better resources, as in non-urban streams.

In-stream features, especially substrate were related with a perturbation gradient: gravel, pebbles and cobbles were associated to the wider urban reaches, while silt were representative of the narrow pools from non-urban streams. Despite the importance of riparian forest as the main source of allochthonous resources (Pusey and Arthington 2003), land use in many hydrographic basins will continue to be used in human activities, such as agriculture and livestock. Therefore, conservation measures should be encouraged (see examples in Casatti et al. 2015) to stimulate the increase of in-stream variability if it is intended to promote fish diversity avoiding functional redundancy (Bordignon et al. 2015; Casatti et al. 2015; Ceneviva-Bastos et al. 2017).

Flexible diets are one of the most striking features of Neotropical fish (Lowe-McConnell 1999). Fish may change food consumption in response to food supply as a result of environmental fluctuations (Abelha et al. 2001). Fish species with generalist and opportunistic feeding habits are more

Table 7 Percentage of similarity analysis (SIMPER) for food items consumed by the fish in four urban and five non-urban reaches. Overall average dissimilarity: $81.92 \%$. U = Mean abundance in urban sections; $\mathrm{NU}=$ Mean abundance in non-urban sections

\begin{tabular}{lllll}
\hline Item & Contribution & Cumulative \% & $\mathrm{U}$ & $\mathrm{NU}$ \\
\hline Chironomidae larvae & 23.92 & 29.2 & 1.44 & 0.52 \\
Detritus & 21.54 & 55.5 & 1.17 & 0.61 \\
Terrestrial adult insect & 15.98 & 75 & 0.23 & 1 \\
Vegetal material & 15.84 & 94.34 & 0.31 & 0.81 \\
Trichoptera larvae & 4.64 & 100 & 0.07 & 0.22 \\
\hline
\end{tabular}


tolerant to habitat alterations than specialist species. The species $A$. bockmanni and A. fasciatus, were more abundant in urban streams, omnivores and representatives of the Characidae family. Among the Neotropical fishes, many characins stand out for having omnivorous food habits and for great feeding plasticity (Barros et al. 2016). It is possible that these characins are benefited from the changes in food supply caused by urbanization in these streams. On the other hand, the South American darters (Crenuchidae family) are generally more specialized (e.g. insectivores) and consequently sensitive, as well as some species of small catfishes of the family Heptapteridae (Casatti et al. 2012).

Detritus plays an important role in aquatic systems, affecting the trophic structure of communities (Moore et al. 2004). Detritus increased its importance in urbanized areas, as seen elsewhere (Oliveira and Bennemann 2005; Bonato et al. 2012). Only omnivorous fish as Phalloceros reisi consumed high proportion of detritus in urban reaches. Considering the low nutritional value and digestibility of detritus in relation to other items (Bowen 1983), we inferred that the increase in consumption was due to its higher availability compared to other items. Fish diets usually correspond to the availability of the food resources, while maintaining some differences related to its preference or easiness of catching the food (Maroneze et al. 2011). In continental waters of the southeastern region of Brazil, Phalloceros species are common and well adapted to the lentic environments (Lucinda 2008). In addition, tolerant species may be favored by habitat modifications as a result of anthropogenic actions (Morgan and Cushman 2005) that often reduce environmental variability, as discussed. Aquatic habitats may be physically altered by detritus (Casatti et al. 2012), which may facilitate or inhibit the presence of fish species (Zeni and Casatti 2014). Land use alteration can increase availability of detritus and favor omnivorous and opportunistic fish (Noel et al. 1986).

Chironomid larvae also increased its importance in urban reaches compared to non-urban sections, for both invertivores and omnivores. Although Chironomid is a family rich in species and with distinct ecological adaptations, it is also recognized by its tolerance to environmental degradation (Pedersen and Perkins 1986; Lammert and Allan 1999; Callisto et al. 2001; Nerbonne and Vondracek 2001; Cavaca et al. 2014), although the Chironomidae family is rich in species, with distinct ecological characteristics. Probably, the increase of chironomid larvae consumption may be due to its higher abundance in urban sections or even the reduction of other resources, which makes fish dependent on fewer taxa.

Changes in diet may also occur because of changes in foraging tactics (Casatti et al. 2009a; Teresa and Casatti 2012). The Heptapteridae and Crenuchidae species present in this study are benthivorous fish with specialized body morphology that allow them to forage in runs among branches, rocks, pebble and boulder (Uieda and Pinto 2011; Rezende et al.
2013), and favors the obtaining of food in places inaccessible to other species (Cetra et al. 2011). In this sense, these invertivorous species can have their foraging efficiency reduced by the presence of fine-grained substrates, such as silt. In fact, the decline of invertivorous fish in an expected response to deterioration of the natural condition of the substrate or siltation (Casatti et al. 2009b; Cetra et al. 2011; Cruz et al. 2013; Krause et al. 2013). Otherwise, fish that are capable to forage in midwaters, capturing items adduced by the current (Characidae species, especially Astyanax) (Ferreira and Casatti 2006) or surface foragers as Phalloceros reisi (personal observation), would not have compromised their feeding activity by these substrate modification. Additionally, carried sediments can remain in suspension and increase turbidity of the water (Nerbonne and Vondracek 2001), compromising the foraging of visually-oriented fish (Pringle and Hamazaki 1998).

Urbanization affected fish assemblages by altering the stream environment and food availability, resulting in changes in fish diets. The substrate composition was essential to maintain sensitive fish species in temperate streams (Roy et al. 2006), and fish functional diversity in tropical streams (Casatti et al. 2015). Since less amount of substrates, such as gravel, pebbles and cobbles was found in the silty urban stream reaches, we highlight that the heterogeneity of the substrate is critical to maintain the natural feeding habits of fish species. Currently, we observed that restoration projects focused on physical structure of streams in Brazil, on the occasions when that is accomplished, have been basically focused on riparian reforestation. However, our results suggest that a restoration plan for urban streams cannot be limited to reforestation of its surroundings, but also need to consider the physical structure of the channel, especially the substrate, which contributes to promote in-stream variability.

Acknowledgements We are grateful to people from the UFSCar during data collection, including Bruna Botti Cruz, Bruno Mello, Fernanda Ayumi Teshima and Rodrigo Almeida da Silva. We are also grateful to Dr. Francisco Langeani Neto (UNESP/São José do Rio Preto) for species identification and Fundação de Amparo à Pesquisa do Estado de São Paulo (FAPESP) for financial support (Proc. 2009/53056-8) and scholarship granted to the first author (2010/13758-0). Two anonymous reviewers provided helpful comments on earlier drafts of the manuscript.

We also would like to thanks Fabio M. Suzuki, for very useful help with figure 1 .

\section{References}

Abelha MCF, Agostinho AA, Goulart E (2001) Plasticidade trófica em peixes de água doce. Acta Sci 23:425-434

Abujanra F, Agostinho AA, Hahn NS (2009) Effects of the flood regime on the body condition of fish of different trophic guilds, in the upper Paraná River floodplain, Brazil. Braz J Biol 69(2):469-479 
Allan JD (1995) Stream ecology: structure and function of running water. Chapman \& Hall, New York

Araujo-Lima CARM, Agostinho AA, Fabré N (1995) Trophic aspects of fish communities in Brasilian rivers and reservoir. In: Tundisi JG, Tundisi TM (eds) Limnology in Brazil, pp 105-136

Barletta M, Jaureguizar AJ, Baigun C, Fontoura NF, Agostinho AA, Almeida-Val VMF, Val AL, Torres RA, Jimenes-Segura LF, Giarrizzo T, Fabré NN, Batista VS, Lasso C, Taphorn DC, Costa MF, Chaves PT, Vieira JP, Correa MFM (2010) Fish and aquatic habitat conservation in South America: a continental overview with emphasis on neotropical systems. J Fish Biol 76:2118-2176

Barros G, Zuanon J, Deus C (2016) Effects of species co-occurrence on the trophic-niche breadth of characids in Amazon forest streams. J Fish Biol 90:326-340. https://doi.org/10.1111/jfb.13183

Bojsen BH (2005) Diet and condition of three fish species (Characidae) of the Andean foothills in relation to deforestation. Environ Biol Fish 73:61-73

Bojsen BH, Barriga R (2002) Effects of deforestation on fish community structure in Ecuadorian Amazon streams. Freshw Biol 4:2246-2260

Bonato KO, Delariva RL, Silva JC (2012) Diet and trophic guilds of fish assemblages in two streams with different anthropic impacts in the northwest of Paraná, Brazil. Zoologia 29(1):27-38

Bordignon CR, Casatti L, Pérez-Mayorga MA, Teresa FB, Brejão GL (2015) Fish complementarity is associated to forests in Amazonian streams. Neotrop Ichthyol 13(3):579-590

Boulton AJ, Boyero L, Covich AP, Dobson M, Lake S, Pearson R (2008) Are tropical streams ecologically different from temperate streams? In: Dudgeon D (ed) Tropical stream ecology. Amsterdan, academic press, pp 257-284

Bowen SH (1983) Detritivory in neotropical fish communities. Environ Biol Fish 9:137-144

Braga FMS (1999) O grau de preferência alimentar: um método qualitativo e quantitativo para o estudo do conteúdo estomacal de peixes. Acta Sci 21(2):291-295

Callisto M, Moretti M, Goulart M (2001) Macroinvertebrados Bentônicos como Ferramenta para Avaliar a Saúde de Riachos. Rev Bras Rec Hídr 6(1):71-82

Casatti L, Langeani F, Ferreira CP (2006) Effects of physical habitat degradation on the stream fish assemblage structure in a pasture region. Environ Manag 38:974-982

Casatti L, Ferreira CP, Langeani F (2009a) Fish-based biotic integrity index for assessment of lowland streams in southeastern Brazil. Hydrobiologia 623:173-189

Casatti L, Ferreira CP, Carvalho FR (2009b) Grass-dominated stream sites exhibit low fish species diversity and dominance by guppies: an assessment of two tropical pasture river basins. Hydrobiologia 632:273-283

Casatti L, Teresa FB, Gonçalves-Souza T, Bessa E, Manzotti AR, Gonçalves CS, Zeni JO (2012) From forests to cattail: how does the riparian zone influence stream fish? Neotrop Ichthyol 10(1): 205-214

Casatti L, Teresa FB, Zeni JO, Ribeiro MD, Brejão GL, Ceneviva-Bastos M (2015) More of the same: high functional redundancy in stream fish assemblages from tropical Agroecosystems. Environ Manag 55(6):1300-1314

Cavaca HS, Carvalho MAG, Srbek-Araujo AC (2014) Riqueza e abundância de macroinvertebrados bentônicos em riachos associados a diferentes fitofisionomias sobre a formação Barreiras. Natureza on line 12(5):224-229

Ceneviva-Bastos M, Montana CG, Schalk CM, Camargo PB, Casatti L (2017) Responses of aquatic food webs to the addition of structural complexity and basal resource diversity in degraded Neotropical streams. Austral Ecology

Cetra M, Rondineli GR, Souza UP (2011) Compartilhamento de recursos por duas espécies de peixes nectobentônicas de riachos na bacia do rio Cachoeira (BA). Biota Neotrop 11:1-9
Collier KJ (1995) Environmental factors affecting the taxonomic composition of aquatic macroinvertebrate communities in lowland waterways of northland, New Zealand. New Zeal J Mar Fresh 29(4):453-465

Collier KJ (2014) Wood decay rates and macroinvertebrate community structure along contrasting human pressure gradients (Waikato, New Zealand). New Zeal J Mar Fresh 48(1):97-111

Cottenie K (2005) Integrating environmental and spatial processes in ecological community dynamics. Ecol Lett 8:1175-1182

Cruz BB, Miranda LE, Cetra M (2013) Links between riparian landcover, instream environment and fish assemblages in headwater streams of South-Eastern Brazil. Ecol Freshw Fish 22:607-616

Cunico AM, Agostinho AA, Latini JD (2006) Influência da urbanização sobre as assembléias de peixes em três córregos de Maringá, Paraná. Rev Bras Zool 23(4):1101-1110

Cunico AM, Ferreira EA, Agostinho AA, Beaumord AC, Fernandes R (2012) The effects of local and regional environmental factors on the structure of fish assemblages in the Pirapó Basin, Southern Brazil. Landsc Urban Plan 105:336-344

Daruich J, Tripole S, Gil MA, Vallania A (2013) Algal and Cyanobacterial communities in two rivers of the province of San Luis (Argentina) subjected to anthropogenic influence. Acta Limnol Bras 25(1):79-90

Dudgeon D, Arthington AH, Gessner MO, Kawabata ZI, Knowler DJ, Lévêque C, Naiman RJ, Prieur-Richard AH, Soto D, Stiassny MLJ, Sullivan CA (2006) Freshwater biodiversity: importance, threats, status and conservation challenges. Biol Rev 81:163182

Esselman PC, Allan JD (2010) Relative influences of catchment- and reach-scale abiotic factors on freshwater fish communities in rivers of northeastern Mesoamerica. Ecol of. Freshw Fish 9:439-454

Ferreira CP, Casatti L (2006) Influência da estrutura do hábitat sobre a ictiofauna de um riacho em uma micro-bacia de pastagem, São Paulo, Brasil. Rev Bras Zool 23(3):642-651

Ferreira A, Paula F, Ferraz SFDEB, Gerhard P, Kashiwaqui EAL, Cyrino JEP, Martinelli LA (2012) Riparian coverage affects diets of characids in neotropical streams. Ecol Freshw Fish 21:12-22

Ferreira FC, Silva AT, Gonçalves CS, Petrere Jr M (2014) Disentangling the influences of habitat structure and limnological predictors on stream fish communities of a coastal basin, southeastern Brazil. Neotrop Ichthyol 12(1):177-186

Francis RA (2012) Positioning urban rivers within urban ecology. Urban Ecosyst 15:285-291

Fryirs K, Brierley G (2013) Geomorphic analysis of river systems: an approach to reading the landscape. Wiley-Blackwell, Oxford, p 360

Fundação SEADE (2013) Fundação sistema estadual de análise de dados. http://www.seade.gov.br/produtos/imp/index.php?page $=$ consulta\&action $=$ var list\&busca $=$ Taxa $+\mathrm{de}+$ Urbaniza\%E7\%E3o. Accessed 22 July $201 \overline{3}$

Gonçalves CS, Braga FMS (2012) Changes in ichthyofauna composition along a gradient from clearwaters to blackwaters in coastal streams of Atlantic forest (southeastern Brazil) in relation to environmental variables. Neotrop Ichthyol 10(3):675-684

Hammer O, Harper DAT, Ryan PD (2011) PAST: paleontological statistics software package for education and data analysis. Palaeontol Electron 4(1):9

Harding J, Clapcott J, Quinn J, Hayes J, Joy M, Storey R, Greig H, Hay J, James T, Beech M, Ozane R, Meredith A, Boothroyd I (2009) Stream habitat assessment protocols for wadeable rivers and streams of New Zeland. School of biological sciences, Canterbury educational printing services, New Zeland. Pp. 133

Helms BS, Feminella JW, Pan S (2005) Detection of biotic responses to urbanization using fish assemblages from small streams of western Georgia, USA. Urban Ecosyst 8:39-57

Herder F, Freyhoff J (2006) Resource particional in a tropical fish assemblage. J Fish Biol 69:571-589 
Hlúbiková D, Novais MH, Dohet A, Hoffmann L, Ector L (2014) Effect of riparian vegetation on diatom assemblages in headwater streams under different land uses. Sci Total Environ 475:234-247

Jacobsen D, Cressa C, Mathooko JM, Dudgeon D (2008) Macroinvertebrates: composition, life histories and production. In: Dudgeon D (ed) Tropical stream ecology. Amsterdan, Academic Press, pp 65-106

Karpova GA, Klepets YV (2014) Influence of urban landscapes on the structural indices of Macrophytes in the Vorskla River. Hydrobiol J 50(6):3-16

Krause JR, Bertrand KN, Kafle A, Troelstrup NH Jr (2013) A fish index of biotic integrity for South Dakota's Northern Glaciated Plains Ecoregion. Ecol Indic 34:313-322

Lammert M, Allan JD (1999) Assessing biotic integrity of streams: effects of scale in measuring the influence of land use/cover and habitat structure on fish and Macroinvertebrates. Environ Manag 23(2): $257-270$

Lorion CM, Kennedy BP (2009) Riparian forest buffers mitigate the effects of deforestation on fish assemblages in tropical headwater streams. Ecol Appl 19:468-479

Lowe-McConnell RH (1999) Estudos ecológicos de comunidades de peixes tropicais. Editora da Universidade de São Paulo, São Paulo

Lucinda PHF (2008) Systematics and biogeography of the genus Phalloceros Eigenmann, 1907 (Cyprinodontiformes: Poeciliidae: Poeciliinae), with the description of twenty-one new species. Neotrop Ichthyol 6(2):113-158

Luiz EA, Agostinho AA, Gomes LC, Hahn NS (1998) Ecologia trófica de peixes em dois riachos da Bacia do Rio Paraná. Braz J Biol 58:273-285

Luz-Agostinho KD, Agostinho AA, Gomes LC, HF J-J, Fugi R (2009) Effects of flooding regime on the feeding activity and body condition of piscivorous fish in the upper Paraná River floodplain. Braz J Biol 69(2):481-490

Maroneze DM, Tupinambás TH, Alves CBM, Vieira F, Pompeu PS, Callisto M (2011) Fish as ecological tools to complement biodiversity inventories of benthic macroinvertebrates. Hydrobiologia 673(1):29-40

Moore JC, Berlow EL, Coleman DC, de RPC, Dong Q, Hastings A, Johnson NC, McCann KS, Melville K, Morin PJ, Nadelhoffer K, Rosemond AD, Post DM, Sabo JL, Scow KM, Vanni MJ, Wall DH (2004) Detritus, trophic dynamics and biodiversity. Ecol Lett 7:584-600

Morgan RP, Cushman SF (2005) Urbanization effects on stream fish assemblages in Maryland, USA. J North Am Benthol Soc 24(3): 643-655

Nerbonne BA, Vondracek B (2001) Effects of local land use on physical habitat, benthic macroinvertebrates, and fish in the Whitewater river, Minnesota, USA. Environ Manag 28(1):87-99

Noel DS, Martin CW, Federer CA (1986) Effects of forest clearcutting in New England on stream macroinvertebrates and periphyton. Environ Manag 10(5):661-670

Oksanen J, Blanchet FG, Friendly M, Kindt R, Legendre P, McGlinn D, Minchin PR, O'Hara RB, Simpson GL, Solymos P, Stevens MHH, Szoecs E, Wagner H (2017) Vegan: community ecology package. R package version 2:4-3 https://CRAN.R-project.org/package=vegan

Oliveira DC, Bennemann ST (2005) Ictiofauna, recursos alimentares e relações com as interferências antrópicas em um riacho urbano no sul do brasil. Biota Neotrop 5(1):95-107

Paul MJ, Meyer JL (2001) Streams in the urban landscape. Annu Rev Ecol Syst 32:333-365

Pease AA, Gonzalez-Diaz AA, Rodiles-Hernandez R, Winemiller KO (2012) Functional diversity and trait-environment relationships of stream fish assemblages in a large tropical catchment. Freshwat Biol 57:1060-1075. https://doi.org/10.1111/j.1365-2427.2012.02768.x
Pedersen ER, Perkins MA (1986) The use of benthic invertebrate data for evaluating impacts of urban runoff. Hydrobiologia 139:13-22

Peres-Neto PR, Jackson DA (2001) How well do multivariate data sets match? The advantages of a procrustean superimposition approach over the mantel test. Oecologia 129:169-178

Peressin A, Cetra M (2014) Responses of the ichthyofauna to urbanization in two urban areas in Southeast Brazil. Urban Ecosyst 17(3): $675-690$

Pinto BCT, Araujo FG, Hughes RM (2006) Effects of landscape and riparian condition on a fish index of biotic integrity in a large southeastern Brazil river. Hydrobiologia 556:69-83

Pringle CM, Hamazaki T (1998) The role of omnivory in a neotropical stream: separating diurnal and nocturnal effects. Ecology 79(1): 269-280

Pusey BJ, Arthington AH (2003) Importance of the riparian zone to the conservation and management of freshwater fish: a review. Mar Freshw Res 54:1-16

R Core Team (2013) R: a language and environment for statistical computing. In: R Foundation for Statistical Computing, Vienna, Austria. URL https://www.R-project.org/

Ramírez A, Pringle CM, Wantzen KM (2008) Tropical stream conservation. In: Dudgeon D (ed) Tropical stream ecology. Academic, Amsterdan, pp 285-300

Rezende CF, Lobón-Cerviá J, Caramaschi EP, Mazzoni R (2013) Trophic ecology of two benthivorous fishes in relation to drift and benthos composition in a pristine Serra do mar stream (Rio de Janeiro, Brazil). Fundam Appl Limnol 183(2):163-175

Roy AH, Freeman MC, Freeman BJ, Wenger SJ, Meyer JL, Ensign WE (2006) Importance of riparian forests in urban catchments contingent on sediment and hydrologic regimes. Environ Manag 37(4): 523-539

Sato Y, Godinho HP (1999) Peixes do rio São Francisco. In: LoweMcconnell RH (ed) Estudos ecológicos de comunidades de peixes tropicais. Editora da Universidade de São Paulo, São Paulo 535pp

Silva JC, Delariva RL, Bonato KO (2012) Food-resource partitioning among fish species from a first-order stream in northwestern Paraná, Brazil. Neotrop Ichthyol 10(2):389-399

Smith WS, Biagioni RC, Halcsik L (2013) Fish fauna of Floresta Nacional de Ipanema, São Paulo State, Brazil. Biota Neotrop 13(2). http://www.biotaneotropica.org.br/v13n2/en/abstract? inventory+bn01713022013

Suren AM (2000) Effects of urbanization. In: Collier KJ, Winterbourn MJ (eds) New Zealand stream invertebrates: ecology and implications for management. New Zeland Limnological Society, Hamilton, pp 260-288

Teresa FB, Casatti L (2012) Influence of forest cover and mesohabitat types on functional and taxonomic diversity of fish communities in Neotropical lowland streams. Ecol Freshw Fish 21:433-442

Tófoli RM, Alves GHZ, Higuti J, Cunico AM, Hahn NS (2013) Diet and feeding selectivity of a benthivorous fish in streams: responses to the effects of urbanization. J Fish Biol 83:39-51

Uieda VS, Pinto TLF (2011) Feeding selectivity of ichthyofauna in a tropical stream: space-time variations in trophic plasticity. Community Ecol 12:31-39

Vermonden K, Leuven RSEW, van der Velde G, van Katwijk MM, Roelofs JGM, Hendriks AJ (2009) Urban drainage systems: an undervalued habitat for aquatic macroinvertebrates. Biol Conserv 142:1105-1115

Wantzen KM, Yule CM, Mathooko JM, Pringle CM (2008) Organic matter processing in tropical streams. In: Dudgeon D (ed) Tropical stream ecology. Amsterdan, Academic Press, pp 43-64

Zeni JO, Casatti L (2014) The influence of habitat homogenization on the trophic structure of fish fauna in tropical streams. Hydrobiologia 726:259-270 